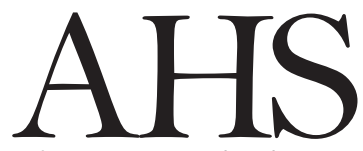

Advances in Horticultural Science

\section{Hexachlamys edulis (Berg) Kausel \& Legrand, "ubajay", a native fruit species from South America}

\author{
I.S. Povilonis, M.E. Arena, S. Radice \\ Laboratorio de Fisiología Vegetal Universidad de Morón (UM - CONICET), \\ Machado 914, Morón, B1708EOH Buenos Aires, Argentina.
}

Key words: Ethnobotany, Myrtaceae, nutraceutical fruit.

\begin{abstract}
Hexachlamys edulis (Berg) Kausel \& Legrand, "ubajay" is a native fruit species from South America belonging to the Myrtaceae family. Undoubtedly, it is a prominent species that provides potentially nutraceutical fruits, leaves with secondary metabolites of interest, and other organs with great benefits for human health and new alternatives for production systems. The aim of this work is to carry out a bibliographic review of all the scientific material published on this species to date. Research of this species could reveal and register its ethnobotanical potential.
\end{abstract}

\footnotetext{
${ }^{(*)}$ Corresponding author:

ipovilonis@unimoron.edu.ar
}

Citation:

POVILONIS I.S., ARENA M.E., RADICE S., 2021 Hexachlamys edulis (Berg) Kausel \& Legrand, "ubajay", a native fruit species from South America. - Adv. Hort. Sci., 35(4): 389-397

\section{Copyright:}

(c) 2021 Povilonis I.S., Arena M.E., Radice S. This is an open access, peer reviewed article published by Firenze University Press

(http://www.fupress.net/index.php/ahs/) and distributed under the terms of the Creative Commons Attribution License, which permits unrestricted use, distribution, and reproduction in any medium, provided the original author and source are credited.

Data Availability Statement:

All relevant data are within the paper and its Supporting Information files.

Competing Interests:

The authors declare no competing interests.

Received for publication 26 February 2021 Accepted for publication 2 August 2021

\section{Introduction}

South America occupies a prominent place with 263 underutilized fruit species, among which several of them play an important role in food and human nutrition. They have compounds that make them functional foods, have resilience to inclement weather, resist biotic stress and finally have important genes for their breeding (Brauch, 2016).

Furthermore, these species are underutilized for various reasons such as: the ignorance of their nutritional value and commercial potential, botanical misinformation, lack of promotion and popularization and the rapid disappearance of the ecosystem due to habitat destruction.

Non-traditional fruits are considered to play an important role in mitigating the problems of world food in a context with growing population and malnutrition (Nandal and Bhardwaj, 2014; Dandin and Krishna Kumar, 2016; S Ajay Vino and Sinija, 2016).

In addition, Denardin et al. (2015) support that there is substantial evidence of the beneficial effects of diets rich in fruits and vegetables.

There is a preference to choose the consumption of fruits with superior qualities; thus, their health benefits and perception as exotic have led to a growing demand from consumers disposed to pay higher prices than the most traditional fruits (González Vega, 2013). However, little is known about these species, and it is essential to research for being part of our economic, social and cultural heritage (Alonso and Desmarchelier, 2014). 
Hexachlamys edulis (O. Berg) Kausel \& D. Legrand, "ubajay" (H. edulis) is certainly a prominent species, distributed naturally in an important area of South America, which provides potentially nutraceutical fruits, leaves with secondary metabolites of interest, and other usable organs that provide great benefits for human health and new alternatives for production systems.

The aim of this study was to conduct a review of all scientific literature on $\mathrm{H}$. edulis to date.

\section{Materials and Methods}

In order to get comprehensive information on this species, we have extensively explored available databases like Science Direct, Google Scholar, Mendeley and PubMed.

In total, we selected 55 articles through database searching with the names "Eugenia myrcianthes", "Hexachlamys edulis" and "Myrcianthes edulis".

Finally, the articles were used for data extraction and analysis, which were related to endemic area, systematic and phylogeny, morphological characterization, chemistry composition and ethnobotany.

\section{Results}

\section{Endemic area}

There are no references about $H$. edulis distribution on another continent, therefore it can be confirmed that this is an endemic species of South America. Area of collection and conservation of this species by different researchers is showed in figure 1 .

Hexachlamys edulis has been studied or cited in the Argentina provinces of Entre Ríos, Corrientes, Misiones, Santa Fe, Formosa and Chaco. In Uruguay it grows spontaneously in Soriano, Río Negro, Paysandú and Artigas departments, while in Paraguay it was found in Central and Cordillera departments. Finally, in Brazil its distribution was more widespread to Rio Grande do Sul, Paraná, Santa Catarina, Mato Grosso do Sul, Minas Gerais, Sao Paulo and Goiás states.

Hexachlamys edulis has been observed in areas near water courses, where Paraná, Uruguay and Paraguay rivers are the most important. Also, it has been referred in gallery forest, delta, islands and the Paranaense jungle.

According to these studies and mentions, $H$. edulis

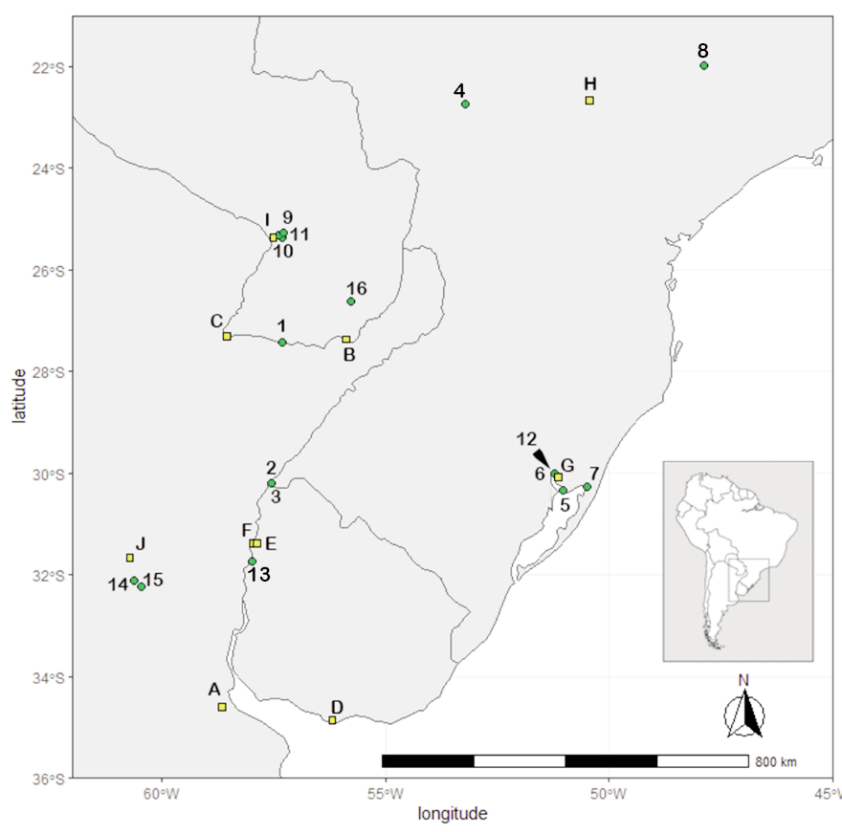

Fig. 1 - Map showing the collection sites of Hexachlamys edulis samples cited in this study. The circles represent samples collected from wild populations and the squares show material from herbaria or non-wild populations. Data was compiled using Microsoft Excel and R programming language (R Core Team, 2018).

\begin{tabular}{|c|c|c|}
\hline References & Latitude S & Longitude W \\
\hline A Molina, 2016 & $34^{\circ} 36^{\prime} 34.96^{\prime \prime}$ & $58^{\circ} 40^{\prime} 31.31^{\prime \prime}$ \\
\hline B Lorca et al., 1995 & $27^{\circ} 21^{\prime} 53.28^{\prime \prime}$ & $55^{\circ} 53^{\prime} 36.84^{\prime \prime}$ \\
\hline C Franceschini, 2000 & $27^{\circ} 18^{\prime} 34.35^{\prime \prime}$ & $58^{\circ} 33^{\prime} 44.03^{\prime \prime}$ \\
\hline D Grela, 2004 & $34^{\circ} 51^{\prime} 32.03^{\prime \prime}$ & $56^{\circ} 11^{\prime} 58.76^{\prime \prime}$ \\
\hline E González, 2003 & $31^{\circ} 22^{\prime} 36.55^{\prime \prime}$ & $57^{\circ} 58^{\prime} 34.22^{\prime \prime}$ \\
\hline F Vignale and Bisio, 2005 & $31^{\circ} 23^{\prime} 5.84^{\prime \prime}$ & $57^{\circ} 53^{\prime} 3.79^{\prime \prime}$ \\
\hline G Kinupp and De Barros, 2008 & $30^{\circ} 4^{\prime} 11.54^{\prime \prime}$ & $51^{\circ} 8^{\prime} 23.17^{\prime \prime}$ \\
\hline H Branco et al., 2016 & $22^{\circ} 39^{\prime} 16.36^{\prime \prime}$ & $50^{\circ} 26^{\prime} 13.43^{\prime \prime}$ \\
\hline I Schmeda-Hirschmann, 1995 & $25^{\circ} 21^{\prime} 14.12^{\prime \prime}$ & $57^{\circ} 31^{\prime} 9.01^{\prime \prime}$ \\
\hline J Rozycki et al., 1997 & $31^{\circ} 40^{\prime} 8.99^{\prime \prime}$ & $60^{\circ} 43^{\prime} 44.47^{\prime \prime}$ \\
\hline 1 Cecotto et al., 2007 & $27^{\circ} 25^{\prime} 52.04^{\prime \prime}$ & $57^{\circ} 19^{\prime} 25.70^{\prime \prime}$ \\
\hline 2 Cardoso Marchiori and Santos, 2010 & $30^{\circ} 12^{\prime} 26.71^{\prime \prime}$ & $57^{\circ} 33^{\prime} 35.91^{\prime \prime}$ \\
\hline 3 Santos et al., 2014 & $30^{\circ} 12^{\prime} 26.68^{\prime \prime}$ & $57^{\circ} 33^{\prime} 33.27^{\prime \prime}$ \\
\hline 4 Romagnolo and Souza, 2004 & $22^{\circ} 45^{\prime} 2.92^{\prime \prime}$ & $53^{\circ} 13^{\prime} 20.05^{\prime \prime}$ \\
\hline 5 Da Cruz, 2012 & $30^{\circ} 20^{\prime} 43.71^{\prime \prime}$ & $51^{\circ} 1^{\prime} 26.89^{\prime \prime}$ \\
\hline 6 Da Cruz, 2012 & $30^{\circ} 3^{\prime} 7.35^{\prime \prime}$ & $51^{\circ} 10^{\prime} 32.41^{\prime \prime}$ \\
\hline 7 Da Cruz, 2012 & $30^{\circ} 15^{\prime} 52.20^{\prime \prime}$ & $50^{\circ} 29^{\prime} 59.84^{\prime \prime}$ \\
\hline 8 Takao et al., 2015 & $21^{\circ} 58^{\prime} 29.68^{\prime \prime}$ & $47^{\circ} 52^{\prime} 28.53^{\prime \prime}$ \\
\hline 9 Theoduloz et al., 1988 & $25^{\circ} 21^{\prime} 36.36^{\prime \prime}$ & $57^{\circ} 19^{\prime} 48.44^{\prime \prime}$ \\
\hline 10 Rodriguez et al., 1992 & $25^{\circ} 18^{\prime} 19.62^{\prime \prime}$ & $57^{\circ} 23^{\prime} 13.40^{\prime \prime}$ \\
\hline 11 Schmeda-Hirschmann et al., 1996 & $25^{\circ} 16^{\prime} 0.56^{\prime \prime}$ & $57^{\circ} 17^{\prime} 3.71^{\prime \prime}$ \\
\hline 12 Apel et al., 2005 & $30^{\circ} 0^{\prime} 21.60^{\prime \prime}$ & $51^{\circ} 14^{\prime} 13.28^{\prime \prime}$ \\
\hline 13 Bertucci et al., 2008 & $31^{\circ} 43^{\prime} 30.03^{\prime \prime}$ & $58^{\circ} 0^{\prime} 1.48^{\prime \prime}$ \\
\hline 14 Fagundez, 2011 & $32^{\circ} 06^{\prime} 196^{\prime \prime}$ & $60^{\circ} 38^{\prime} 255^{\prime \prime}$ \\
\hline 15 Fagundez, 2011 & $32^{\circ} 13^{\prime} 212^{\prime \prime}$ & $60^{\circ} 27^{\prime} 51.4^{\prime \prime}$ \\
\hline 16 Dujak, 2015 & $26^{\circ} 36^{\prime} 36.09^{\prime \prime}$ & $55^{\circ} 46^{\prime} 26.88^{\prime \prime}$ \\
\hline
\end{tabular}


is distributed at least in one million $\mathrm{Km}^{2}$.

\section{Systematics and phylogeny}

Myrtaceae family has 131 genera and more than 4620 species (Stevens, 2017) and up to 5800 species according to Stefanello et al. (2011). The family is divided into two large tribes according to the fruit consistence: Leptospermeae if the fruit is dry or Myrteae if it is fleshy.

The Myrteae tribe or subfamily, contains three subtribes: Myrcinae Berg, Orthotestimoninae Berg, and Eugeniinae Berg. The latter tribe includes the genus Hexachlamys (Legrand, 1962) that presents approximately 10 species distributed in South America (Cruz et al., 2011), among which is $H$. edulis.

Authors cited the species $H$. edulis with several names and also including it in different genera (Table 1). Psidium amygdalinum (Hooker and Arnott, 1833) is the oldest available name for this species. Sometime later the species was named Myrcianthes edulis by O. Berg, and then Bentham and Hooker rename this taxon to Eugenia. This species became known as Eugenia edulis until Niedenzu showed that the name already existed and introduced Eugenia myrcianthes Nied. Finally, Kausel and Legrand published the new nomenclature as Hexachlamys (Proença, 2006).

The name $H$. edulis was first published in 1950 and since 1968 the genus Hexachlamys was independent (McVaugh, 1968). Hexachlamys was differentiated from Eugenia by Berg based on the number of chalice pieces and the embryo morphology. Flowers of Eugenia gender have tetrameric chalice while those of Hexachlamys have pentameric or hexameric calix, and the embryo of Hexachlamys have hypocotyl visible and exserted and cryptic in Eugenia (Da Cruz et al., 2013); however, some authors considered this argument inconsistent to separate the genus (Ciarlante, 2003; Da Cruz, 2012).

Other names used for the species were Luma grisebachii, Luma myrcianthes, Myrtus excelsa, Calomyrtus excelsa, Myrcia gemmiflora (eds), Campomanesia cagaiteira, Myrcia sparsifolia, Hexachlamys excelsa, Eugenia montevidensis, Eugenia edulis ex Grisebac, Myrciaria edulis Skeels, Myrciaria plicatocostata O. Berg, Eugenia plicatocostata Glaz, Marlierea edulis Nied, Plinia anonyma Sobral, Plinia edulis Vell, Plinia plicatocostata O. Berg Amshoff (Rotman, 1982; Borges et al., 2014).

Since the publication of Mattos (1995) and Landrum and Kawasaki (1997) it was discussed whether Hexachlamys should be considered as a different genus or as a synonym of Eugenia.

In addition, new phylogenetic molecular analysis have revealed that Hexachlamys species do not form a monophyletic clade, so the Hexachlamys proposal as a synonym for Eugenia was corroborated (Cruz et al., 2011; Da Cruz, 2012; Da Cruz et al., 2013; Mazine et al., 2014, 2016, 2018).

Mazine et al. (2018) suggested more consistent and stable classification: Hexachlamys as a subgenus of Eugenia. This last denomination, $H$. edulis, is the most currently used as is observed in figure 2 (Proença, 2006; GBIF, 2019).

Different authors (Niedenzu, 1893; Mattos, 1995; Landrum and Kawasaki, 1997; Sobral, 2003; Proença, 2006; Da Cruz, 2012; Mazine et al., 2014, 2016;

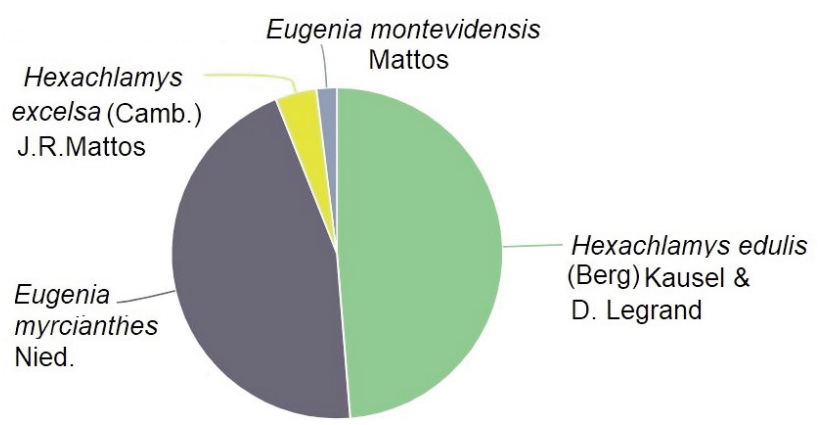

Fig. 2 - Different names used to classify Hexachlamys edulis. Figure taken from GBIF (2019).

Table 1 - Different names assigned to the species by botanists over the years

\begin{tabular}{|c|c|c|c|c|c|}
\hline \multirow{2}{*}{ Year } & \multicolumn{5}{|c|}{ Botanists } \\
\hline & Hooker \& Arnott & O. Berg & Bentham \& Hooker & Niedenzu & Kausel \& Legrand \\
\hline 1833 & Psidium amygdalinum & & & & \\
\hline 1857 & & Myrcianthes edulis & & & \\
\hline 1865 & & & Eugenia edulis & & \\
\hline 1893 & & & \multicolumn{3}{|c|}{ Eugenia myrcianthes } \\
\hline 1950 & & & & & Hexachlamys edulis \\
\hline
\end{tabular}


WCSP, 2020) argue that it is correct to accept the synonymy between $H$. edulis (Berg) Kausel \& Legrand and Eugenia myrcianthes Nied.

\section{Morphological characterization}

Hexachlamys edulis is a fruit tree with globular treetop (Fig. 3A), with an altitude up to 10 meters according to Rotman (1982), 12 meters according to Legrand and Klein (1977), Cardoso Marchiori and Santos (2010) and 15 meters by Dematté (1997).

Persistence of the foliage is contradictory (Carrere, 2008). Rotman (1982) consider this species as evergreen but in Uruguay it shows leaf fall from late May to late August and blooming at the begin- ning of the spring without leaves. Foliage unfolds later, when the anthesis declines and vegetative growth stops in early December (González, 2003). A more exhaustive observation allowed determining that this species is phanerophytes - by the aerial location of its buds (Raunkiaer, 1934) - and deciduous with concomitant foliar renewal and that apparently low temperatures accelerate defoliation (González, 2003).

Leaves are described as petiolated, with a coriaceous leaf blade, pubescent, oval or elliptic-oblong, briefly acuminate, obtuse base, (3-) 5-9 cm of length by (1-) $2.5-3.4 \mathrm{~cm}$, reticulate venation, with the median nerve prominent on the abaxial face; pubescent

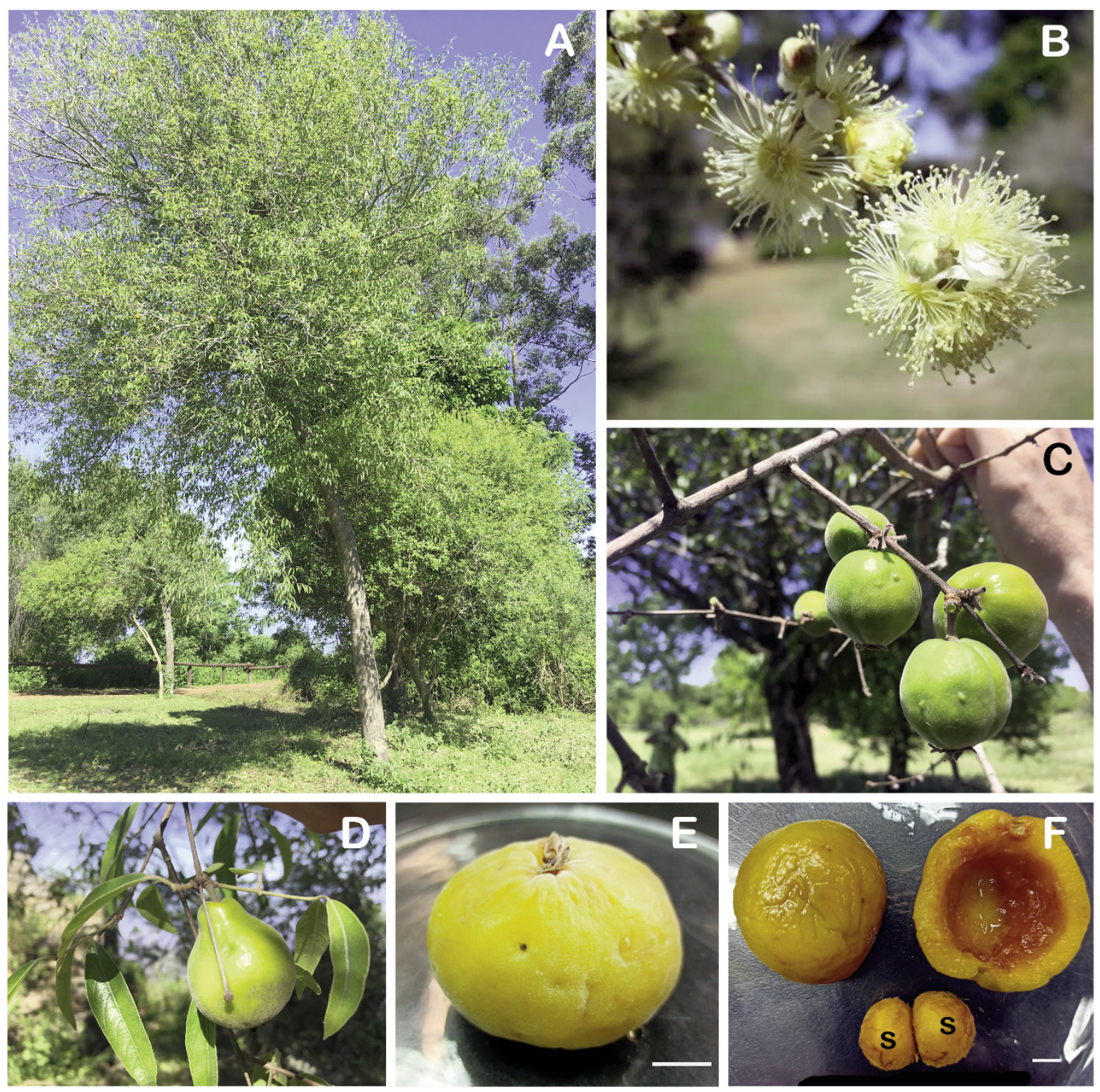

Fig. 3 - Hexachlamys edulis grown in Argentina. (A) tree grown in Parque Nacional El Palmar, Entre Ríos; (B) cluster of flowers; (C-D) inmature fruit; (C) globose; (D) piriform; (E-F) mature fruit; (F) disected fruit with seeds (s). Bars $=1 \mathrm{~cm}$. 
petioles, (3-) 7-10 mm of length (Rotman, 1982). Lorca et al. (1995) described polygonal to sinuous cells of various sizes and sparse trichomes stand out in the adaxial epidermis; the cuticle is thick and striated. In their abaxial epidermis they describe abundant single celled trichomes and clustered and raised stomata. Stomata are paracytic, that is, they have 2 adjoining cells arranged parallel to the occlusive cells. Also, the presence of hypodermis towards the adaxial face, palisade parenchyma 1-stratified and spongy parenchyma 5-6-stratified, with large intercellular spaces stand out. The central rib has flabeliform xylem and phloem in bundles located on the abaxial and adaxial sides of the xylem. Sclerenchymal sheath interrupted on the sides. Collenchyma present on the abaxial side and 3-4 hypodermis stratified on the adaxial side.

Flowers are typical of Myrtaceae; appear in the leaf axils in apical position, are white, solitary and hermaphroditic (Fig. 3B). Rotman (1982) describes clusters with 2-4 flowers with pubescent pedicels from 1 to $22 \mathrm{~mm}$ in length, puberulous, linear lanceolate, up to $5 \mathrm{~mm}$ in length; pubescent hypanthus; sepals (4-) 5, puberulous, deltoid, acute, persistent, 3-5 mm in length; petals (4-) 5, obtuse, ciliolate, pubescent on the outer, face spacedly hairy on the inner face, 5-9 $\mathrm{mm}$ length; stamens 5-9 $\mathrm{mm}$ in length, pubescent staminal disc; 2-3 locular ovary with axillary placentation. Although there are no morphological references of nectariferous glands, Fagundez (2011) cites $H$. edulis as a native pollennectariferous species of interest.

Flowering season is variable according to diferent the researchers. Flowering, occurs from August to January in northeastern Argentina, in the department of Artigas, Uruguay, and in Asunción, Paraguay by Rotman (1982). Instead, for Dematté (1997) it happens between August and November, that is, it reduces the range, without specifying the location, while Vignale and Bisio (2005) reports a shorter flowering period, during September, in Salto, Uruguay. In the same locality, González (2003) observes that in early October flowering declines and ends entirely in the middle of the month. For plants grown in the locality of Lajeado, Brazil, Guizzo and Jasper (2005) recorded flowering from August to September. Finally, Fagundez (2011) found that $H$. edulis reaches full bloom during the month of October in Diamante, Argentina.

Fruit is a globose drupe (Lughadha and Proenca, 1996) with a yellow color, about $5 \mathrm{~cm}$ in maximum equatorial diameter (Lorenzi et al., 2000) and up to $50 \mathrm{~g}$ of fresh weight in the mature state. Fruit set and ripening occur in a few weeks, staggered from mid October to the end of November when the harvest can be done (Vignale and Bisio, 2005). Rotman (1982) describes an edible fruit, globose or piriform (Fig. 3CD), up to $9 \mathrm{~cm}$ long. Fruits are yellow, up to $4 \mathrm{~cm}$ in diameter according to González (2003). It is a barely fluffy fruit, with an orange flesh, very juicy, with a slightly sour taste and a pungent odor when fully ripe (www.descubriendocorrientes2012.com) (Fig. 3E-F). Also, it has been described as sweet sour, pleasant, and a quickly maturing (González, 2003) and as a very acidic fruit (Chebez and Masariche, 2010). However, other authors have characterized the ripe fruit by a disgusting smell, although it would seem that there is great diversity in the fruits between genotypes (Vignale and Bisio, 2005), to which Carrere (2008) attributes that more or less fruits could be found pleasant to smell depending on the subjectivity of those who perceive it.

Regarding to associated pathologies, González (2003) found that most of the fruits had insect bites, but without specifications; only Rossini et al. (2015) cites $H$. edulis as host of Anastrepha fraterculus (Wiedemann).

The seed is exalbuminated, globose and during germination it remains enclosed by a woody structure that some authors interpreted as endocarp (Rotman, 1982) (Fig. 3F); but it has not been anatomically corroborated (Franceschini, 2000). It has a single embryo (Lughadha and Proenca, 1996) solid, globose and glabrous (Franceschini, 2000) with fully welded cotyledons. Germination is hypogeal and cryptocotilar.

The seedling is completely covered with simple hairs, undeveloped hypocotyl, light green and cylindrical epicotyl. Alternate membranous cataphylls have acute apex, obtuse base and entire margin. Simple, alternate or opposite nomophiles; petiole ribbed on adaxial face; elliptical blade, chartaceous, light green, sharp apex and base and entire margin (Franceschini, 2000).

\section{Chemistry composition}

Researchers promote the consumption of diets rich in fruits and vegetables due to its health beneficial effects, such as lowering the risk of cardiovascular disease, cancer and conditions associated with aging and oxidative stress (Gomez da Silva et al., 2019). Studies show that these foods can prevent dis- 
eases and disorders due to the presence of bioactive compounds with antioxidant properties. These compounds interfere with biological mechanisms such as the protection against free radicals, cellular signaling mediated for free radicals, inflammation, allergies, platelet aggregation, ulcers, viruses, tumors and hepatotoxicity (Denardin et al., 2015).

Several studies have shown that the fruits of Myrtaceae have antioxidant activity (Borges et al., 2014) due to the presence of anthocyanins, flavonoids, carotenoids or other secondary metabolites.

In particular, $H$. edulis fruit would have great potential as a functional food due to its compositional profile, outstanding nutritional value (Vignale and Bisio, 2005), very favorable for health, and considering that its vitamin content has been highlighted (Cecotto et al., 2007). In addition, fruit has vitamin C quantified in $75.1 \mathrm{mg} / 100 \mathrm{~g}$ of fresh matter (Rozycki et al., 1997). Also, different phenolic compounds $(2181.42 \mathrm{mg}$ GAE/100 g of dry matter), carotenoids ( $242.53 \mu \mathrm{g} / \mathrm{g}$ of dry matter) and antioxidant activity (153.09 $\mu \mathrm{mol}$ Trolox Equivalent/g of dry matter) have been quantified (Branco et al., 2016). It also stands out for its protein content of $8.05 \%$ in dry matter, and good relative amounts of Zinc and Boron minerals (Kinupp and De Barros, 2008).

Hexachlamys edulis was noted for its high content of total pectin $(403.5 \mathrm{mg} / 100 \mathrm{~g}$ ) in fresh fruits tissue (Rozycki et al., 1997). This high content explains the excellent quality of the fruit jelly of this species cited by Kinupp and De Barros (2008).

All these data show the potential of this fruit tree, especially for the fruit pulp, juice and jelly agroindustry. However, this species is not considered yet by Brazilian fruit producers and researchers (Kinupp and De Barros, 2008), unlike the manifest interest observed in other countries of South America.

On the other hand, the leaf of the species belonging to the Myrtaceae is the most used plant organ in South America for medicinal purposes (Camelo Munevar, 2016), and perhaps for this reason, the chemical composition of the leaves has been the most studied. $H$. edulis leaves contain steroid triterpenes, low molecular weight terpenes, tannins, polyphenols, saponins, alkaloids, flavonoids, and glycosides (Bertucci et al., 2008). Flavonoid glycosides: myricetin 3-O-rhamnoside; myrcetin 3-O-pentoside; quercetin 3-O-pentoside; quercetin 3-O-rhamnoside and myricetin deoxyhexoside-gallate (SchmedaHirschmann, 1995; Schmeda-Hirschmann et al., 1996;
Celli et al., 2010; Takao et al., 2015). Essential oils have a predominance of sesquiterpenes, of which $\beta$ selinen $(16.1 \%), \beta$-caryophyllene $(8.3 \%)$ and $\delta$ cadinene $(8.3 \%)$ are the most abundant (Apel et al., 2005). Also, Borges et al. (2014) found $\beta$-caryophyllene, its oxide and caryophyllene oxide (39.3\%).

\section{Ethnobotany}

According to Legrand and Klein (1977), H. edulis is a species frequently cultivated in Rio Grande do Sul (Brazil), for its tasty and fragrant fruits. Fruits are consumed fresh, in jams, juices, jellies (Da Cruz, 2012) and ice creams have been made with great acceptance. Kozel (1991) describes that consumption of $\mathrm{H}$. edulis fruits favor fights bladder stones and nephritic stones. Also, two Mbyá Guaraní communities of the San Rafael Park Reserve harvest the fruit for food (Dujak et al., 2015). The fruit is considered by some people to be slightly laxative (Lorenzi et al., 2000).

Leaves are widely used as infusions in Brazil for the treatment of bronchitis, cough, whooping cough (Camelo Munevar, 2016) and diabetes (Rodriguez et al., 1992). H. edulis leaf extract causes a significant response in blood glucose levels due to its rich content of flavonoids and tannins. In addition, Lorca et al. (1995), highlight its use for the treatment of diabetes in the form of herbal teas or with mate. Consumption was reaffirmed by Pirondo et al. (2011), due to the supply of the product in the markets of Corrientes, Argentina. Other authors highlighted the benefits of the leaves and their medical use to reduce uric acid due to the inhibition of the enzyme xanthine oxidase, producer of uricate, whose excess is considered to cause hyperuricemia in gout (a form of inflammatory arthritis) (Lio et al., 1985). Theoduluz et al. (1988) analyzed $H$. edulis leaves and it was proved to be the most active among the 15 species in a comparative study.

Other possible secondary uses are the production of vinegar from the fruit (Carrere, 2008) or production of essential oils from its flowers (Cecotto et al., 2007). Also, its wood is useful (Molina, 2016) due to it is moderately heavy, hard, compact and resistant, suitable for common carpentry, tool handles, turning (Cardoso Marchiori and Santos, 2010) and its bark can be used in the chemical industry for the preparation of white ink and tannins (Carrere, 2008). It is used as alternative forage in Paraguarí, Paraguay (Benítez and Bertoni, 2015) or can also be used for reestablishing native woodland or forest gardens 
(Lorenzi, 2002). Chebez and Masariche (2010) includes $H$. edulis in their list of healing trees.

$H$. edulis is known by many vernacular names such as "ubajay" and due to its similarity to the peach (Prunus persica L. Batsch.), it is called "duraznero de monte" (in Argentina and Uruguay) (Hanelt et al., 2001). Also, H. edulis was named "iba hay", "ibajai", "igu jhay mi", "uva jy" (Legrand, 1941; Rotman, 1982) and "Clagye locoic" in Mocovic lenguage (Rosso and Scarpa, 2012). In Brazil it is known as "cereja do rio grande", "ocorocil lo", "cerejeira", "ivai", "pessegueiro bravo", "pêssego do mato", "ubajaí" and "ibajai" (Romagnolo and Souza, 2004; Proença, 2006). In Paraguay it is known as "yvahái" (Dujak et al., 2015).

\section{Conclusions}

Despite the ecological and economic importance, little is known about this species of the genus Hexachlamys, so it is important to revalue its use. $H$. edulis (O. Berg) Kausel \& D. Legrand, "ubajay" research could reveal and record its ethnobotanical potential based on the chemical composition of its fruits and other organs. At the same time, we refer to a species with the possibility of cultivation that offers the opportunity to diversify production, in this case, for farmers on the Argentine coast, southern Brazil, Paraguay, western Uruguay, and why not in a future, in other regions.

\section{Acknowledgements}

This work was supported by the Secretariat of Science and Technology of the University of Morón PICT/18-06-MA-009.

\section{References}

ALONSO J., DESMARCHELIER C., 2014 - Plantas medicinales autóctonas de la Argentina: bases científicas para su aplicación en atención primaria de la salud. - 1ed. Corpus Libros Médicos y Científicos, CABA, Argentina.

APEL M.A., SOBRAL M., MENUT C., BASSIERE J.M., ZUANAZZI J.Á., SCHAPOVAL E.E.S., 2005 - Volatil constituents of four Hexachlamys species growing in South Brazil. - Flavour Fragance Journal, 20: 176-179.

BENÍTEZ B., BERTONI S., 2015 - Diversidad y homogeneidad de especies arbóreas y arbustivas utilizadas como forrajeras alternativas en área de influencia del Arroyo Caañabé, Departamento Paraguarí-Paraguay. Steviana, 7: 57-73.

BERTUCCI A., HARETCHE F., OLIVARO C., VÁZQUEZ A., 2008 - Prospección química del bosque en galería de río Uruguay. - Revista Brasileira de Farmacognosia, 18(1): 21-25.

BORGES L.L., CARDOSO CONCEIÇÃO E., SILVEIRA D., 2014 Active compounds and medicinal properties of Myrciaria genus. - Food Chemistry, 153: 224-233.

BRANCO I.G., KIKUCHI T.T., SANJINEZ ARGANDONA E.J., FREITAS MORAES I.C., HAMINIUK C.W.I., 2016 - Drying kinetics and quality of uvaia ( $\mathrm{H}$. edulis) powder obtained by foam-mat drying. - Int. Jof Food Sci. Techn., 51: 1703-1710.

BRAUCH J.E., 2016 - Underutilized fruits and vegetables as potential novel pigment sources. - Handbook on Natural Pigments in Food and Beverages, pp. 305-335.

CAMELO MUNEVAR D.O., 2016 - Contribución al estudio fitoquímico de frutos de Syzygium paniculatum G. y evaluación de su actividad antioxidante. Undergraduate thesis, Universidad Francisco José de Caldas, Bogotá, Colombia.

CARDOSO MARCHIORI J.N., SANTOS S.R. DOS, 2010 Anatomía das madeiras de campomanesiaaurea $O$. Berg e Eugenia myrcianthes Niedenzu (Myrtaceae). Balduinia, 22: 23-30.

CARRERE R., 2008 - El ubajai (Hexachlamis edulis): un árbol frutal indígena. - https://www.guayubira.org.uy/ monte/Ubajai.pdf.

CECOTTO J.A., TAIARIOL D.R., CÁCERES S., 2007 - Colección de frutos tropicales de la EEA INTA Bella Vista. Publicación Técnica, no. 21.

CELLI G.B., PEREIRA NETTO A.B., BETA T., 2010 Comparative analysis of total phenolic content, antioxidant activity, and flavonoids profile of fruits from two varieties of brazilian cherry (Eugenia uniflora L.) throughout the fruit developmental stages. - Food Research International, 44: 2442-2451.

CHEBEZ J.C., MASARICHE M., 2010 - Trees of Argentina. Albatros, Buenos Aires, Argentina, pp. 128.

CIARLANTE C.S., 2003 - Sinópsis de géneros y taxones supragenéricos de Argentina. - http://www. floraargentina.edu.ar/wp-content/uploads/2019/05/80-MYRTACEAE, parte3.pdf.

CRUZ F., TURCHETTO ZOLET A., VETO N., MONDIN C., ALMERÃO M., MARGIS R., 2011 - Molecular phylogenetics of the genus Hexachlamys (Myrtaceae) using chloroplast and nuclear markers. - BMC Proceedings, 5(7): 6.

DA CRUZ F., 2012 - Sistemática e filogenética molecular do genero Hexachlamys (Myrtaceae) a través do uso de marcadores plastidiais e nucleares. - PhD Thesis, Universidad Fệderal do Rio Grande, Rio Grande, Brazil, 
pp. 71

DA CRUZ F., TURCHETTO ZOLET A.C., VETO N., MONDIN C.A., SOBRAL M., ALMERÃO M., 2013 - Phylogenetic analysis of the genus Hexachlamys (Myrtaceae) based on plastid and nuclear DNA sequences and their taxonomic implications. - Botanical Journal of the Linnean Society, 172(4): 532-543.

DANDIN S.B., KRISHNA KUMAR N.K., 2016 - Neglected and underutilized fruit species: an insurance against global mal and under nutrition. - http://www.fao.org/ fileadmin/templates/rap/files/meetings/2016/161203_session1_4.pdf.

DEMATTÉ M.E.R.P., 1997 - Ornamental use of Brazilian Myrtaceae. - Acta Horticulturae, 452: 143-180.

DENARDIN C.C., HIRSCH G.E., DA ROCHA R.F., VIZZOTTO M., HENRIQUES A.T., MOREIRA J.C.F., GUMA F.T.C.R., EMANUELLI T., 2015 - Antioxidant capacity and bioactive compounds of four Brazilian native fruits. - J. Food Drug Analysis, 23(3): 387-398.

DUJAK M.M., FERRUCCI S., VERA JIMÉNEZ M., PINEDA J., CHAPARRO E., BRÍTEZ M., 2015 - Registros sobre las especies vegetales alimenticias utilizadas por dos comunidades indígenas Mbyá - Guaraní de la Reserva para Parque Nacional San Rafael, Itapúa - Paraguay. Steviana, 7: 25-47.

FAGUNDEZ G.A., 2011 - Estudio de los recursos nectaríferos y poliníferos utilizados por Apis mellifera L. en diferentes ecosistemas del Departamento Diamante (Entre Ríos, Argentina). - PhD Thesis, Universidad Nacional del Sur, Bahía Blanca, Argentina.

FRANCESCHINI M.C., 2000 - Morfología de embriones y plántulas de especies leñosas del nordeste argentino. Bonplandia, 10(1-4): 143-154.

GBIF, 2019 - Catalogue of Life. Species 2000 \& ITIS Catalogue of Life - https://www.gbif.org/es/ species/5418198.

GOMES DA SILVA A.P., SPRICIGO P.C., PURGATTO E., ALENCAR S.M., SARTORI S.F., JACOMINO A.P., 2019 Chemical composition, nutritional value and bioactive compounds in six uvaia accessions. - Food Chemistry, 294: 547-556.

GONZÁLEZ S., 2003 - Ritmos de follaje y floración en algunas plantas leñosas nativas. - Agrociencia, 7(2): 27-38.

GONZÁLEZ VEGA M.E., 2013 - Chirimoya (Annona cherimola Miller), frutal tropical y subtropical de valores promisorios. - Cultivos Tropicales, 34(3): 52-63.

GRELA I., 2004 - Geografía florística de las especies arbóreas de Uruguay: propuesta para la delimitación de dendrofloras. - MSc. Thesis, Universidad de la República, Montevideo, Uruguay.

GUIZZO D.J., JASPER A., 2005 - Levantamiento das espécies arbóreas dos passeios das vias públicas do bairro americano de lajeado - $R S$, com indicação de solução de problemas já existentes pesquisas. - Botânica, 56: 185208.

HANELT P., BUTTNER R., MANSFELD R., 2001 - Mansfeld's encyclopedia of agricultural and horticultural crops. - 1 ed. Springer, Berlín, Germany.

HOOKER W.J., ARNOTT G., 1833 - Botanical miscellany. London 3, 317. - https://biodiversity library.org/page /779258\#page/318/mode/1up.

KINUPP V.F., DE BARROS I.B.I., 2008 - Protein and mineral contents of native species, potential vegetables, and fruits. - Ciencia e Tecnologia de Alimentos, 28(4): 846857.

KOZEL C., 1991 - Guia de medicina natural. - Plantas Medicinales, 2: 495.

LANDRUM L.R., KAWASAKI M.L., 1997 - The genera of Myrtaceae in Brazil: an illustrated synoptic treatment and identification keys. - Brittonia, 49: 508-536.

LEGRAND D., 1941 - Lista preliminar de las mirtáceas argentinas. - Darwiniana, 5: 463-486.

LEGRAND D., 1962 - Lista actual de las mirtáceas de Argentina. - Boletín de la Sociedad Argentina de Botánica, X(1): 46-51.

LEGRAND D., KLEIN R.M., 1977 - Mirtáceas: Campo-manesia, Feijoa, Britoa, Myrrhinium, Hexachlamys, Siphoneugena, Myrcianthes, Neomitranthes, Psidium. In: REITZ P.R. (ed.) Flora llustrada Catarinense. Herbário Barbosa Rodrigues, Itajaí, pp. 571-730.

LIO M., MORIYAMA A., MATSUMOTOA Y., TAKAKIA N., FUKUMOTOA M., 1985 - Inhibition of Xanthine oxidase by flavonoids. - Agric. Biol. Chem., 49(7): 2173-2176.

LORCA G.G., AMAT A.G., GONZÁLEZ C. 1995 - Análisis comparativo de caracteres diagnósticos para la Identificación de tres especies Argentinas de myrtaceae empleadas en la medicina popular. - Acta Farm. Bonaerense, 14(2): 81-86.

LORENZI H., 2002 - Brazilian trees. - Publisher Instituto Plantarum De Estudos Da Flora, Brazil.

LORENZI H., BACHER L., LACERDA, M., SARTORI S., 2000 Brazilian fruits and cultivated exotics publication. Instituto Plantarum De Estudios Da Flora, LTDA, Brazil.

LUGHADHA E.M., PROENCA C., 1996 - A survey of the reproductive biology of the myrtoideae (Myrtaceae). Annals of the Missouri Botanical Garden, 83(4): 480503.

MATTOS J.R., 1995 - Novidades taxonômicas em Myrtaceae IX. - Loefgrenia, 105: 1-3.

MAZINE F.F., 2016 - Sections in Eugenia (Myrteae, Myrtaceae): nomenclatural notes and a key. Phytotaxa, 289(3): 225-236.

MAZINE F.F., QUINTINO FARIA J.E., GIARETTA A., VASCONCELOS T., FOREST F., LUCAS E., 2018 Phylogeny and biogeography of the hyper-diverse genus Eugenia (Myrtaceae: Myrteae), with emphasis on E. sect. Umbellatae, the most unmanageable clade. - Taxon, 67(4): 752-769.

MAZINE F.F., SOUZA V.C., SOBRAL M., FOREST F., LUCAS E., 2014 - A preliminary phylogenetic analysis of Eugenia (Myrtaceae: Myrteae), with a focus on Neotropical species. - Kew Bulletin, 69: 94-97. 
MCVAUGH, 1968 - The genera of American Myrtaceae: An interim report. - Taxon, 17: 354-418.

MOLINA A.M., 2016 - El Jardín Botánico Arturo E. Ragonese (JBAER): miradas a través del tiempo, realidad y prospectiva. - 1ed. Ediciones INTA, BA, Argentina.

NANDAL U., BHARDWAJ R.L., 2014 - The role of underutilized fruits in nutritional and economic security of tribals: a review. - Crit. Rev. Food Sci. Nutr., 54(7): 880890.

NIEDENZU F., 1893 - Myrtaceae. - In: PRANTL K., and A. ENGLER (eds.) Die Natürlichen Pflanzenfamilien, 3: 57105.

PIRONDO A., COULLERI J.P., KELLER H.Á., FERRUCCI M.S., 2011 - External factors influence the marketing of medicinal plants in an urban environment: the case of creoles and indigenous vendors in Corrientes, Argentina. Boletín Latinoamericano y del Caribe de Plantas Medicinales y Aromáticas 10(6): 553-569.

PROENÇA C.E.B., 2006 - Proposal to conserve the name Myrcianthes edulis against Psidium amygdalinum (Myrtaceae). - Taxon, 55(2): 536-537.

R CORE TEAM, 2018 - R: A Language and Environment for Statistical Computing. - R Foundation for Statistical Computing. Vienna, Austria.

RAUNKIAER, 1934 - The life forms of plants and statistical plant geography; being the collected papers of $C$. Raunkiaer. - Oxford University Press, London, UK, pp. 632.

RODRIGUEZ J., LOYOLA J., SCHMEDA-HIRSCHMANN G., 1992 - Hypoglycaemic activity of Hexachlamys edulis ('Yvahai') extract in Rats. - Phytotherapy Res., 6: 47-49.

ROMAGNOLO M.B., SOUZA M., 2004 - Os gêneros Calycorectes $O$. Berg, Hexachlamys O. Berg, Myrcianthes O. Berg, Myrciaria O. Berg e Plinia L. (Myrtaceae) na planície alagável do alto rio Paraná, Brasil. - Acta Bot. Bras., 18(3): 613-627.

ROSSINI M.N., DUMMEL D.M., AGOSTINI J.P., 2015 Plagas cuarentenarias de frutales de la República Argentina Avances en los resultados. - 1ed. Ediciones INTA. Allen, RN, Argentina.

ROSSO C.N., SCARPA G.F., 2012 - Identificaciones botánicas de las plantas empledas entre los Mocovies en la Reducción San Javier durante el siglo XVIII a partir de la obra de Florián Paucke. - Etnobotánica en zonas áridas y semiáridas del Cono Sur de Sudamérica. Edición CEFYBO-CONICET, Buenos Aires, Argentina.

ROTMAN A.D., 1982 - Los géneros Calycorectes, Hexachlamys, Myrciaaria, Paramyrciaria, Plinia y Siphoneugena en la flora argentina (Myrtaceaea). Darwiniana, 24(1-4): 157-185.

ROZYCKI V.R., BAIGORRIA C.M., FREYRE M.R., BERNARD C.M., ZANNIER M.S., CHARPENTIER M., 1997 Composición de nutrientes en especies vegetales autóctonas de la región Chaqueña, Argentina. - Archivos Latinoamericanos de Nutrición, 47(3).

S AJAY VINO H., SINIJA V.R., 2016 - Underutilized fruits in Indian. - Indian Food Industry Mag, 35(2): 45-46.

SANTOS S.R., CARDOSO MARCHIORI J.N., SIEGLOCH A.M., 2014 - Diversidade estrutural em Eugenia L. (Myrtaceae). - Ciência Florestal, 24(3): 785-792.

SCHMEDA-HIRSCHMANN G., 1995 - Flavonoids from Calycorectes, Campomanesia, Eugenia and Hexachlamys species. - Fitoterapia, 66(4): 373-374.

SCHMEDA-HIRSCHMANN G., ZÚÑIGA J., DUTRA BEHRENS M., HABERMEHL G., 1996 - Xanthine Oxidase inhibitory activity of flavonoids and tannins from Hexachlamys edulis (Myrtaceae). - Phytotherapy Res., 10(3): 260262.

SOBRAL M., 2003 - A família Myrtaceae no Rio Grande do Sul. - 1ed. Unisinos Press, São Leopoldo, RGS, Brasil.

STEFANELLO M.E.A., PASCOAL A.C.R.F., SALVADOR M.J., 2011 - Essential oils from neotropical Myrtaceae: Chemical diversity and biological properties. Chemistry and Biodiversity, 8: 73-94.

STEVENS P.F., 2017 - Angiosperm phylogeny website. http://www.mobot.org/MOBOT/research/APweb/.

TAKAO L.K., IMATOMI M., GUALTIERI S.C.J. 2015 Antioxidant activity and phenolic content of leaf infusions of Myrtaceae species from Cerrado (Brazilian Savanna). - Braz. J. Biol., 75(4): 948-952.

THEODULOZ C., FRANCO L., FERRO E., SCHMEDAHIRSCHMANN G., 1998 - Xanthine oxidase inhibitory activity of paraguayan myrtaceae. - J. Ethnopharm., 24(2-3): 179-183.

VIGNALE B., BISIO L., 2005 - Selección de frutales nativos en Uruguay. - Agrociencia, 9(1-2), 41- 51.

WCSP, 2020 - World checklist of selected plant families. http://www.kew.org/wcsp/ myrtaceae. 
